\title{
Cholera Toxin Inhibits Signal Transduction by Several Mitogens and the In Vitro Growth of Human Small-Cell Lung Cancer
}

\author{
J. Viallet, ${ }^{\star \ddagger}$ Y. Sharoni, ${ }^{\star \boldsymbol{5}}$ H. Frucht, ${ }^{\|}$R. T. Jensen," J. D. Minna, ${ }^{\star \star}$ and E. A. Sausville ${ }^{\star \$}$ \\ ${ }^{*}$ National Cancer Institute-Navy Medical Oncology Branch, National Cancer Institute, ${ }^{\ddagger}$ Department of Medicine, Uniformed Services \\ University of the Health Sciences, Bethesda, Maryland 20814; "Digestive Diseases Branch, National Institute of Diabetes and \\ Digestive and Kidney Diseases, Bethesda, Maryland 20892; and \$Division of Medical Oncology, "Department of Medicine, \\ Vincent T. Lombardi Cancer Research Center, Georgetown University School of Medicine, Washington, D.C. 20007
}

\begin{abstract}
Cholera toxin (CT) inhibited the in vitro growth of three of four human small-cell lung carcinoma (SCLC) cell lines with a 50\% inhibitory concentration of 27-242 $\mathrm{ng} / \mathrm{ml}$. Loss of surface membrane ruffling and the capacity of $\left[\mathrm{Tyr}^{4}\right]$-bombesin, vasopressin, and fetal calf serum to stimulate increases in intracellular free calcium clearly preceded effects on cellular metabolic activity and cell growth. ${ }^{125} \mathrm{I}-\left[\mathrm{Tyr}^{4}\right]$-bombesin binding was unaffected by CT treatment but [Tyr $\left.{ }^{4}\right]$-bombesin stimulated phospholipase $\mathrm{C}$ activity was decreased in membranes from CT-treated SCLC cells. CT stimulated a rapid but transient increase in intracellular cyclic AMP ([CAMP $\left.]_{i}\right)$ in SCLC. The effects of CT on susceptible SCLC were not reproduced by elevations of $[\mathrm{cAMP}]_{i}$ induced by forskolin or cyclic AMP analogues. $\mathrm{G}_{\mathrm{M} 1}$ ganglioside, the cellular binding site for $\mathrm{CT}$, was highly expressed in the CT-sensitive but not the CT-resistant SCLC cell lines. In contrast, expression of guanine nucleotide binding protein substrates for ADP-ribosylation by CT was similar. These data demonstrate the existence of a CT-sensitive growth inhibitory pathway in SCLC-bearing $G_{M 1}$ ganglioside. Addition of $\mathrm{CT}$ results in decreased responsiveness to several mitogenic stimuli. These results suggest novel therapeutic approaches to human SCLC. (J. Clin. Invest. 1990. 86:1904-1912.) Key words: cyclic adenosine monophosphate • G protein - gastrin-releasing peptide $\cdot$ growth factor $\cdot$ phospholipase C
\end{abstract}

This work was presented in part at the annual meeting of the American Federation for Clinical Research, Washington, DC, May 1988, and at the Biology of Cellular Transducing Signals '89, Ninth International Washington Spring Symposium, George Washington University, 8-12 May 1989, and has been published in abstract form (1988. Clin. Res. 36:501A).

Dr. Sharoni's current address is Faculty of the Health Sciences, Ben-Gurion University of the Negev, Beer-Sheva, Israel.

Address reprint requests to Dr. Viallet, Montreal General Hospital, Division of Oncology, 1650 Cedar Ave., Montreal, Quebec, Canada H3G 1 A4.

Received for publication 14 March 1990 and in revised form 27 August 1990.

J. Clin. Invest.

(C) The American Society for Clinical Investigation, Inc.

0021-9738/90/12/1904/09 \$2.00

Volume 86, December 1990, 1904-1912

\section{Introduction}

Human small-cell lung carcinoma (SCLC) ${ }^{1}$ produces gastrinreleasing peptide (GRP), the mammalian homologue of the amphibian peptide bombesin (1). Bombesin agonists increase the cloning efficiency of SCLC in serum-free conditions (2) and inhibition of SCLC cell growth can be demonstrated in vitro and in vivo after exposure to a monoclonal anti-bombesin antibody (3) or to bombesin peptide receptor antagonists $(4,5)$. In these experiments, growth inhibition occurred by blocking the interaction of GRP with its receptor. A different approach to interrupt growth factor action would be the disruption of intracellular signaling pathways activated by GRP.

Previous studies in $\operatorname{SCLC}(6,7)$, murine fibroblasts (8), and rat insulinoma cells (9) have shown that binding of GRP to its receptor results in activation of phospholipase $C$, increased phosphatidylinositol (PI) turnover, release of calcium from internal stores, increase of intracellular free calcium $\left(\left[\mathrm{Ca}^{2+}\right]_{i}\right)$, and activation of protein kinase $\mathrm{C}$. Receptors that transduce signals through phospholipase $\mathrm{C}$ may be coupled to this effector by guanine nucleotide binding proteins (G proteins) (10). Certain $\mathrm{G}$ proteins can be covalently modified by the bacterial exotoxins, cholera toxin (CT) and pertussis toxin (PT). CT binds to a cell surface glycolipid, $\mathrm{G}_{\mathrm{M} \text { I }}$ ganglioside, through its $\beta$ subunits. After internalization, the $\alpha$ subunit of CT stimulates ADP-ribosylation of the stimulatory $G$ protein of adenylyl cyclase, $\mathrm{G}_{\alpha \mathrm{s}}$. This action leads to an elevation of intracellular cAMP levels in most cellular systems (11). In addition, activated $\mathrm{G}_{\alpha \mathrm{s}}$ has been shown to increase the activity of calcium channels in skeletal muscle membranes (12).

We recently demonstrated that pretreatment of the SCLC cell line NCI-H345 with cholera toxin (CT) at $1 \mu \mathrm{g} / \mathrm{ml}$ for $18 \mathrm{~h}$ resulted in a substantial inhibition in basal and GRP-stimulated increases in inositol phosphates and $\left[\mathrm{Ca}^{2+}\right]_{i}(7)$. These findings led us to study the effects of $\mathrm{CT}$ on in vitro growth in

1. Abbreviations used in this paper: [cAMP $]_{\mathrm{i}}$, intracellular cyclic adenosine $3^{\prime}, 5^{\prime}$ monophosphate concentration; $\left[\mathrm{Ca}^{2+}\right]_{\mathrm{i}}$, free intracellular calcium concentration; CT, cholera toxin; CT $-\beta$, the $\beta$ subunit of cholera toxin; GRP, gastrin-releasing peptide; $G$ protein, guanine nucleotide binding protein; $\mathrm{IP}_{2}$, inositol biphosphates; $\mathrm{IP}_{3}$, inositol triphosphates; MTT, 3-[4,5-dimethylthiazol-2-yl]-2,5-diphenyltetrazolium bromide; PI, phosphatidylinositol; PIP, phosphatidylinositol monophosphate; $\mathrm{PIP}_{2}$, phosphatidylinositol biphosphate; PT, pertussis toxin; SCLC, human small-cell lung carcinoma. 
four SCLC cell lines. We demonstrate here the existence of a CT-sensitive, membrane-related growth inhibitory pathway which may be exploitable for the development of novel therapeutic approaches to human small-cell lung cancer.

\section{Methods}

Reagents and cell culture. CT, PT, the $\beta$ subunit of CT (CT- $\beta)$, and horseradish peroxidase conjugated to CT- $\beta$ were from List Biologicals Inc. (Campbell, CA). $\left[\mathrm{Tyr}^{4}\right]$-bombesin and $\left[\mathrm{Arg}^{8}\right]$-vasopressin were from Peninsula Laboratories, Inc., Belmont, CA. 3-[4,5-Dimethylthiazol-2-yl]-2,5-diphenyltetrazolium bromide (MTT), quin-2 AM, ionomycin, forskolin, $\mathrm{G}_{\mathrm{M} \text { 1 }}$ ganglioside, GTP, ATP, 5'-0-[3-thiotriphosphate] (GTP- $\gamma-S)$, diaminobenzidine, and thymidine were from Sigma Chemical Co., St. Louis, MO. ${ }^{125} \mathrm{I}$-protein A (sp act $>30 \mathrm{mCi} / \mathrm{mg}$ ) and $\left[{ }^{32} \mathrm{P}\right] \mathrm{NAD}$ (sp act $30 \mathrm{Ci} / \mathrm{mmol}$ ) were from New England Nuclear, Boston, MA. $\left[{ }^{3} \mathrm{H}\right]$ inositol (sp act $16 \mathrm{Ci} / \mathrm{mmol}$ ) and cAMP radiobinding assay kits were from Amersham Corp., Arlington Heights, IL.

NCI-H82, NCI-H209, NCI-H345, and NCI-N417 are established human SCLC cell lines (13) maintained in serum-free RPMI-1640 medium (Gibco Laboratories, Grand Island, NY) supplemented with 5 $\mu \mathrm{g} / \mathrm{ml}$ insulin, $10 \mu \mathrm{g} / \mathrm{ml}$ transferrin, and $30 \mathrm{nM}$ sodium selenite ( $\mathrm{R}$ $\mathrm{SIT}$ ) in the presence of penicillin, streptomycin, and fungizone as in Trepel et al. (7).

MTT assay for cell growth. Use of the MTT assay to estimate lung cancer cell growth has been standardized (14) and is based on the ability of mitochondrial dehydrogenases to reduce the MTT salt to a colored formazan product (15). For the experiments with different cell lines, as shown in Fig. 1, 96-well microtiter tissue culture plates (Costar Data Packaging, Cambridge, MA) received 10-30,000 cells per well in $180 \mu \mathrm{l}$ of R-SIT. The agent to be tested was added $24 \mathrm{~h}$ later in $20 \mu \mathrm{l}$ of medium. After $7 \mathrm{~d}$ of incubation, $50 \mu \mathrm{l}$ of $2 \mathrm{mg} / \mathrm{ml}$ solution of MTT was added and incubated at $37^{\circ} \mathrm{C}$ for $4 \mathrm{~h}$, after which the plates were centrifuged, the medium largely withdrawn, dimethylsulfoxide added to solubilize the colored MTT reduction product, and absorbance measured at $540 \mathrm{~nm}$ with an ELISA reader (Biotek Instruments, Inc., Burlington, VT). CT and CT- $\beta$ are supplied in a buffer whose final concentrations in a $1 \mathrm{mg} / \mathrm{ml}$ stock solution are $50 \mathrm{mM}$ Tris, $1 \mathrm{mM}$ sodium EDTA, $3 \mathrm{mM}$ sodium azide, and $200 \mathrm{mM}$ sodium chloride, $\mathrm{pH}$ 7.5. A buffer of the same composition was used as control in these growth experiments with a minimal dilution of 1:200 without effects on cell growth. CT formulated without sodium azide was also used and yielded the same results as CT formulated with azide.

For assays performed to determine the time course of CT effects on $\mathrm{NCI}-\mathrm{H} 345$ (see Fig. 5B), cells were plated in 96-well plates as above. At the specified intervals after addition of CT, MTT was added and cells were further incubated for $90 \mathrm{~min}$ at which time the plates were developed and scored as above.

Dynamic measurements of free $\left[\mathrm{Ca}^{2+}\right]_{i}$. After incubation with or without $\mathrm{CT}$ at $1 \mu \mathrm{g} / \mathrm{ml}$ for the times indicated in figure legends, the cells were washed three times with phosphate-buffered saline (PBS), loaded with quin-2 AM in RPMI-1640 medium, and stimulated with agonists, and $\left[\mathrm{Ca}^{2+}\right]_{i}$ was measured by the change in recorded fluorescence of quin- 2 as described by Heikkila et al. (6).

Phospholipase C activity in SCLC membranes. $\left[{ }^{3} \mathrm{H}\right]$ inositol-labeled membranes were prepared from SCLC cells essentially as described by Straub and Gershengorn (16) with or without CT pretreatment. $\left[\mathrm{Tyr}^{4}\right]$-bombesin treatment in the presence of GTP- $\gamma-\mathrm{S}$ was followed by assay of label in the inositol polyphosphate fraction including inositols bi- and triphosphates $\left(\mathrm{IP}_{2}\right.$ and $\left.\mathrm{IP}_{3}\right)$ as described by Berridge et al. (17) using Dowex resin anion exchange column chromatography. In this assay of activity in membranes, the levels of inositol monophosphates do not change significantly during incubation (18).

${ }^{125} \mathrm{I}$-[ $\left.\mathrm{Tyr}^{4}\right]$-bombesin binding to SCLC. NCI-H345 cells were preincubated overnight at $37^{\circ} \mathrm{C}$ (concentrations of $30 \times 10^{6} \mathrm{cells} /$ flask) with either no additions (control), CT $(1 \mu \mathrm{g} / \mathrm{ml})$, or PT $(1 \mu \mathrm{g} / \mathrm{ml})$. The preparation of the radioligand, conditions of the binding assay, and analysis of the data with the LIGAND program were as previously described (5). Cells were incubated for $120 \mathrm{~min}$ at $37^{\circ} \mathrm{C}$ with $0.05 \mathrm{nM}$ ${ }^{125} \mathrm{I}$-[ $\left.\mathrm{Tyr}^{4}\right]$-bombesin alone or with increasing concentrations of unlabeled bombesin. HPLC analysis of the ${ }^{125} \mathrm{I}-\left[\mathrm{Tyr}^{4}\right]$-bombesin radioligand after incubation with cells without $\mathrm{CT}$ at $37^{\circ} \mathrm{C}$ for $120 \mathrm{~min}$ showed that $<5 \%$ of the radioactivity eluted in a different position from the radiolabeled ligand not incubated in the presence of cells. Under the same conditions, $93 \%$ of the bound radioligand was stripped from the surface of the cells using $0.2 \mathrm{~N}$ acetic acid/0.5 M sodium chloride, $\mathrm{pH} 2.5$, at $4^{\circ} \mathrm{C}$ for $5 \mathrm{~min}$, indicating that under the conditions of our binding assay the tracer is minimally, if at all, internalized.

Determination of $[c A M P]_{i}$. At the indicated times after addition of drug or toxin, cells were centrifuged, washed in PBS, resuspended in $750 \mu \mathrm{l}$ of $1 \mathrm{mM}$ Tris, $\mathrm{pH} 7.4,4 \mathrm{mM}$ EDTA, and sonicated, and an aliquot was removed for protein determination. The samples were boiled for $3 \mathrm{~min}$, clarified, and stored at $-70^{\circ} \mathrm{C}$ until assayed using the cyclic AMP radiobinding assay kit according to instructions of the vendor (Amersham Corp.). Protein content was determined using an assay (Bio-Rad Laboratories, Richmond, CA).

Detection of $G$ proteins in SCLC. Crude membranes were prepared after the cells were washed once in PBS, resuspended in $0.01 \mathrm{M}$ Tris, pH 7.4, $0.1 \mathrm{mM}$ EDTA, $2 \mu \mathrm{M}$ leupeptin, $1 \mu \mathrm{g} / \mathrm{ml}$ aprotinin, and 1 $\mu \mathrm{g} / \mathrm{ml}$ soybean trypsin inhibitor. The cells were disrupted by $30-40$ strokes of a Teflon/glass homogenizer. Nuclei and unbroken cells were removed by centrifugation for $10 \mathrm{~min}$ at $800 \mathrm{rpm}$ and the supernatant was centrifuged for $30 \mathrm{~min}$ in a JA 20 rotor at $20,000 \mathrm{rpm}$ in a centrifuge (Dupont-Sorvall, Newton, CT). The pellet was washed in $5 \mathrm{mM}$ Hepes, $\mathrm{pH} 7.4$, and recentrifuged. These membranes were separated by $10 \%$ SDS polyacrylamide gel electrophoresis (SDS-PAGE) (19), transferred to nitrocellulose, incubated with antibody, and developed with ${ }^{125} I$-protein $A(20)$. Antisera to $G_{\alpha s}, G_{\alpha i}$ isoforms, and $G_{\alpha 0}$ were provided by Dr. A. Spiegel, National Institute of Diabetes and Digestive and Kidney Diseases (21).

Detection of $C T$ substrates in SCLC. ADP-ribosylation reactions were conducted using $100 \mu \mathrm{g}$ of membrane protein at $32^{\circ} \mathrm{C}$ for $30 \mathrm{~min}$ in $0.1 \mathrm{M} \mathrm{K}$ phosphate, pH 7.0, $1 \mathrm{mM} \mathrm{ATP}, 20 \mathrm{mM}$ thymidine, $2.5 \mathrm{mM}$ $\mathrm{MgCl}_{2}, 5 \mathrm{mM}$ dithiothreitol (DTT), $40 \mu \mathrm{g} / \mathrm{ml} \mathrm{CT}$ or PT preactivated by incubation with $50 \mathrm{mM}$ DTT for 10 and $45 \mathrm{~min}$, respectively, $0.8-3.2 \mu \mathrm{M}\left[{ }^{32} \mathrm{P}\right] \mathrm{NAD}(30 \mathrm{Ci} / \mathrm{mmol})$ with or without $0.2 \mathrm{mM} \mathrm{GTP}$ in a final volume of $150 \mu \mathrm{l}$. The incubation was stopped by addition of 20 $\mu \mathrm{l}$ of $100 \%$ trichloroacetic acid (TCA), maintained at $4^{\circ} \mathrm{C}$ for $1 \mathrm{~h}$, and sedimented, and the pellets were washed with $2 \%$ TCA, followed by three washes with water-saturated ether. Proteins were dissolved in Laemmli sample buffer (19) and subjected to SDS-PAGE as above. ADP-ribosylated proteins were detected by autoradiography of the acid-fixed and dried gel.

$G_{M 1}$ ganglioside expression in SCLC. Cells were washed in PBS and $2 \times 10^{6}$ cells lysed in $1.4 \mathrm{ml}$ of $\mathrm{CHCl}_{3} / \mathrm{CH}_{3} \mathrm{OH}(1: 1)$. These were stored overnight at $4^{\circ} \mathrm{C}$ and had solid residue removed. $1 \mathrm{ml}$ was dried, and redissolved in $\sim 30 \mu \mathrm{l}$ of $\mathrm{CHCl}_{3} / \mathrm{CH}_{3} \mathrm{OH}(1: 1)$. The sample was applied to a Bakerflex plastic-backed silica gel sheet (J. T. Baker, Inc., Phillipsburg, $\mathrm{NJ}$ ), and chromatographed in $\mathrm{CHCl}_{3} / \mathrm{CH}_{3} \mathrm{OH} / 0.25 \%$ $\mathrm{KCl}(60: 35: 6)$. The sheet was air-dried, wet with $1 \%$ polyvinylpyrrolidone in PBS for $40 \mathrm{~min}$ at $37^{\circ} \mathrm{C}$ with gentle agitation. CT- $\beta$ conjugated to horseradish peroxidase $(200 \mathrm{ng} / 30 \mathrm{ml})$ was added at $37^{\circ} \mathrm{C}$ for 40 min with mild agitation. The sheets were washed in PBS three times, and developed by incubation with diaminobenzidine $(10 \mathrm{mg} / 30 \mathrm{ml}$ of $0.05 \mathrm{M}$ Tris, pH 7.6, plus $0.1 \mathrm{ml}$ of $30 \% \mathrm{H}_{2} \mathrm{O}_{2}$ ) (22).

\section{Results}

Inhibition of SCLC in vitro growth by CT. CT inhibited growth of SCLC cell lines NCI-H82, NCI-H209, and NCI-H345 with $50 \%$ inhibitory concentrations ranging from 27 to $242 \mathrm{ng} / \mathrm{ml}$ (i.e., 0.32-2.88 nM; Fig. 1). In contrast, SCLC cell line NCI-N417 was resistant to the effects of CT at concentrations 
A: $\mathrm{NCl}-\mathrm{H} 82$

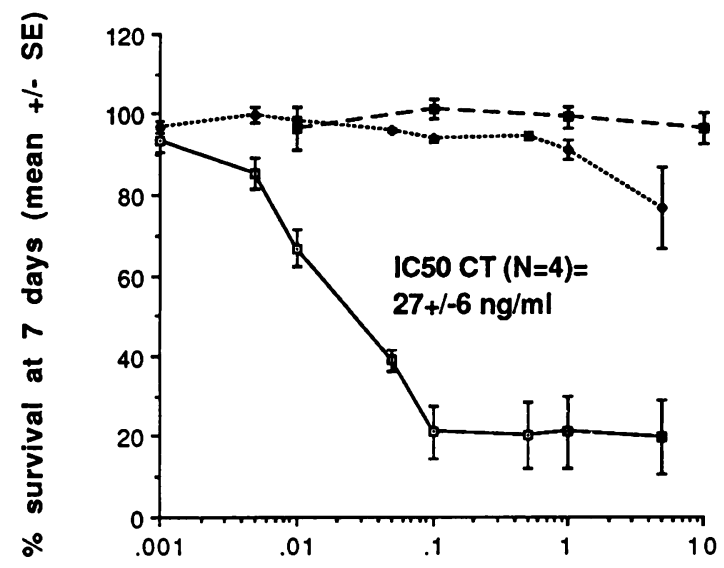

Toxin $(\mu \mathrm{g} / \mathrm{mI})$ or forskolin ( $\mu \mathrm{M})$ concentrations
B: NCl-H2O9

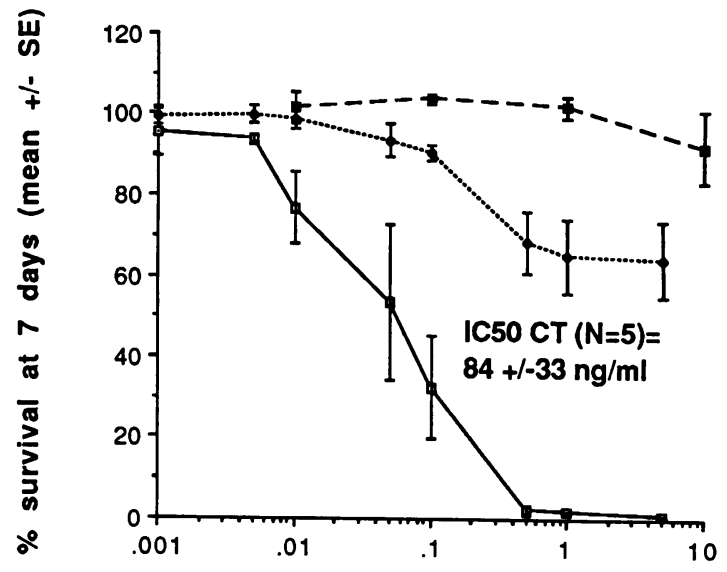

Toxin $(\mu g / \mathrm{ml})$ or forskolin ( $\mu \mathrm{M})$ concentrations
C: NCl-H345

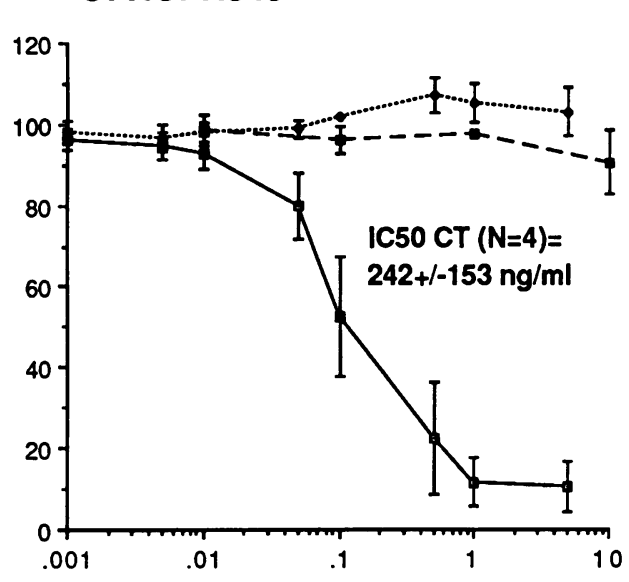

Toxin $(\mu \mathrm{g} / \mathrm{ml})$ or forskolin ( $(\mathrm{MM})$ concentrations

\section{D: NCl-N417}

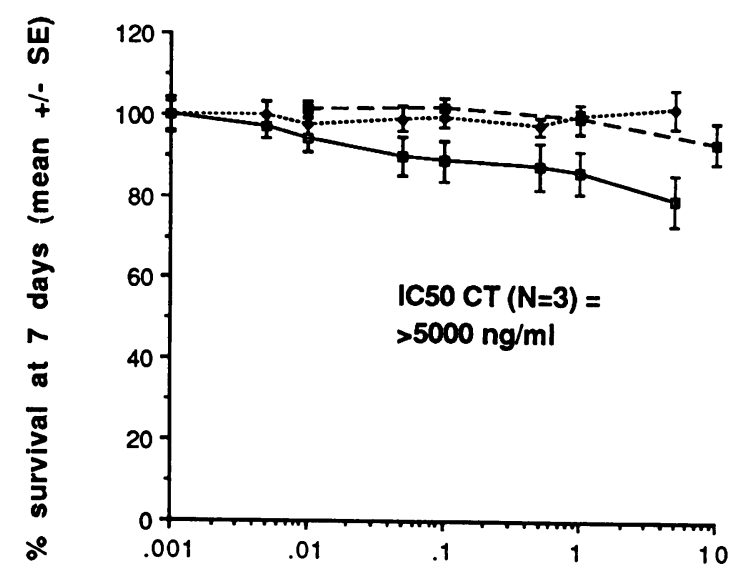

Toxin ( $(\mathrm{g} / \mathrm{ml})$ or forskolin (uM) concentrations

Figure 1. Effects of cholera toxin and forskolin on the growth of SCLC cell lines. Cells were incubated in vitro with CT holotoxin, CT- $\beta$, or forskolin for $7 \mathrm{~d}$ and the viable cell population scored in comparison to an untreated control. The data shown is the mean \pm SE of several exper-

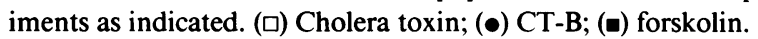

up to $5 \mu \mathrm{g} / \mathrm{ml}$, whereas the $\beta$ subunit of CT had no substantial effects on the growth of any of these cell lines (Fig. 1). Growth inhibition by CT was abrogated by boiling the toxin before the experiment (data not shown). In addition, concentrations of forskolin up to $10 \mu \mathrm{M}$ had no effects on the growth of these four cell lines (Fig. 1). In experiments not shown, concentrations of dibutyryl cAMP up to $1 \mathrm{mM}$ had no effects on the growth of NCI-H345 and showed a modest inhibition of the growth of NCI-H82 (65\% survival at $7 \mathrm{~d}$ compared to control). Similarly, the effects of PT were much less marked than those of CT with the survival at $7 \mathrm{~d}$ at a concentration of $1 \mu \mathrm{g} / \mathrm{ml}$ being $89.1 \%$ for NCI-H82, $73 \%$ for NCI-H209, $56 \%$ for NCI-H345, and $80 \%$ for NCI-N417.

Visual inspection revealed an easily recognizable change in cellular morphology occurring as early as 4-6 $\mathrm{h}$ after exposure to CT. Sensitive cells displayed a loss of membrane ruffles with an overall smoothing of their cell surface (Fig. 2).

$C T$ inhibits intracellular signaling by multiple ligands. The morphological change described above raised the possibility that inhibition of $\left[\mathrm{Tyr}^{4}\right]$-bombesin-induced PI turnover and increase in $\left[\mathrm{Ca}^{2+}\right]_{\mathrm{i}}$ by CT (7) might result from altered membrane structure or function due to an effect of the toxin. If this were the case, alteration of the cellular response not only to GRP but to other mitogenic stimuli as well would be expected. To address this possibility, we studied the response of CTtreated SCLC to additional ligands. Incubation of NCI-H345 cells with CT at $1 \mu \mathrm{g} / \mathrm{ml}$ for $16-18 \mathrm{~h}$ (overnight) results in a substantial inhibition of the increase in $\left[\mathrm{Ca}^{2+}\right]_{i}$ not only in response to [ $\left.\mathrm{Tyr}^{4}\right]$-bombesin, but also in response to vasopressin and serum (Fig. 3). Addition of $2 \mu \mathrm{M}$ ionomycin after exposure to agonists demonstrates that CT treatment did not decrease apparent quin-2 loading or alter the capacity of ionomycin to increase $\left[\mathrm{Ca}^{2+}\right]_{i}$. In fact, the relative response to ionomycin in the absence of extracellular free calcium was preserved in CT-treated cells (data not shown), indicating that CT treatment did not grossly affect intracellular calcium pools.

To examine whether the inhibition of increases in free $\left[\mathrm{Ca}^{2+}\right]_{\mathrm{i}}$ in response to several stimuli described in Fig. 3 could 


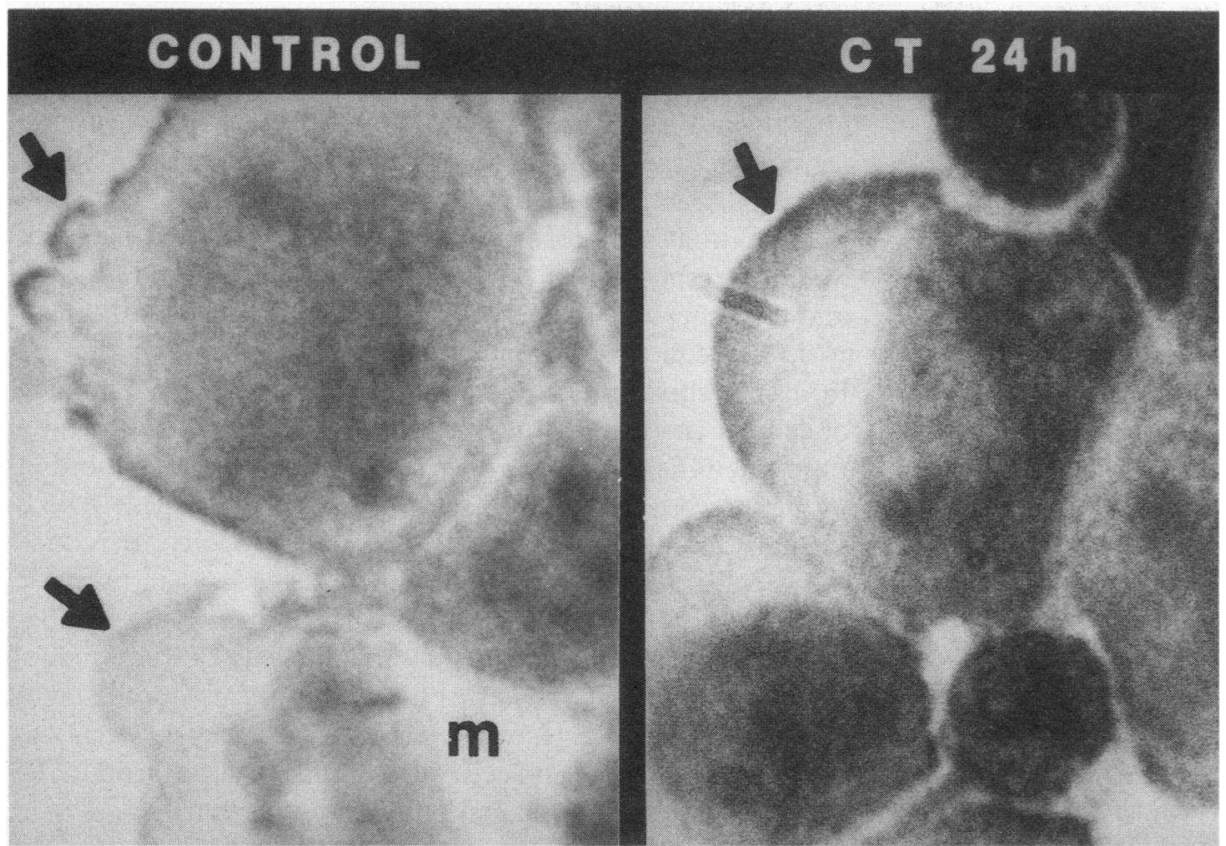

Figure 2. Effect of CT on the morphology of NCI-H345. After an overnight incubation with CT at $1 \mu \mathrm{g} / \mathrm{ml}$, a cytospin preparation was stained with Wright-Giemsa. The CT-treated cells have lost the ruffled cytoplasmic border typical of SCLC (arrows). Cells are viable by Trypan blue exclusion. $(m) \mathrm{A}$ mitosis. be related to $\mathrm{CT}$-induced changes in membrane function, we studied the effect of CT in a subcellular system. SCLC membranes labeled with $\left[{ }^{3} \mathrm{H}\right.$ ]inositol before and during overnight treatment with $1 \mu \mathrm{g} / \mathrm{ml} \mathrm{CT}$ demonstrated decreased activation of phospholipase $\mathrm{C}(P<0.05$ by Student $t$ test) in response to $\left[\mathrm{Tyr}^{4}\right]$-bombesin in the presence of the nonhydrolyzable analogue GTP- $\gamma-S$ (Fig. 4). Under the conditions of this assay, with a $\left[\mathrm{Mg}^{2+}\right]$ free of $0.2 \mu \mathrm{M}, \mathrm{CT}$ treatment leads to a greater activation of phospholipase $\mathrm{C}$ with GTP- $\gamma-\mathrm{S}$ alone $(P<0.05)$. Thus, CT-mediated inhibition of agonist-induced PI turnover is apparent in membrane fractions as well as in the whole-cell assays of soluble $\left[{ }^{3} \mathrm{H}\right]$ inositol phosphate described previously (7).

Since interruption by $\mathrm{CT}$ of [ $\left.\mathrm{Tyr}^{4}\right]$-bombesin-induced signals could reflect inhibition of ligand binding, we studied specific agonist binding to toxin-treated cells. We found that

\section{Control}

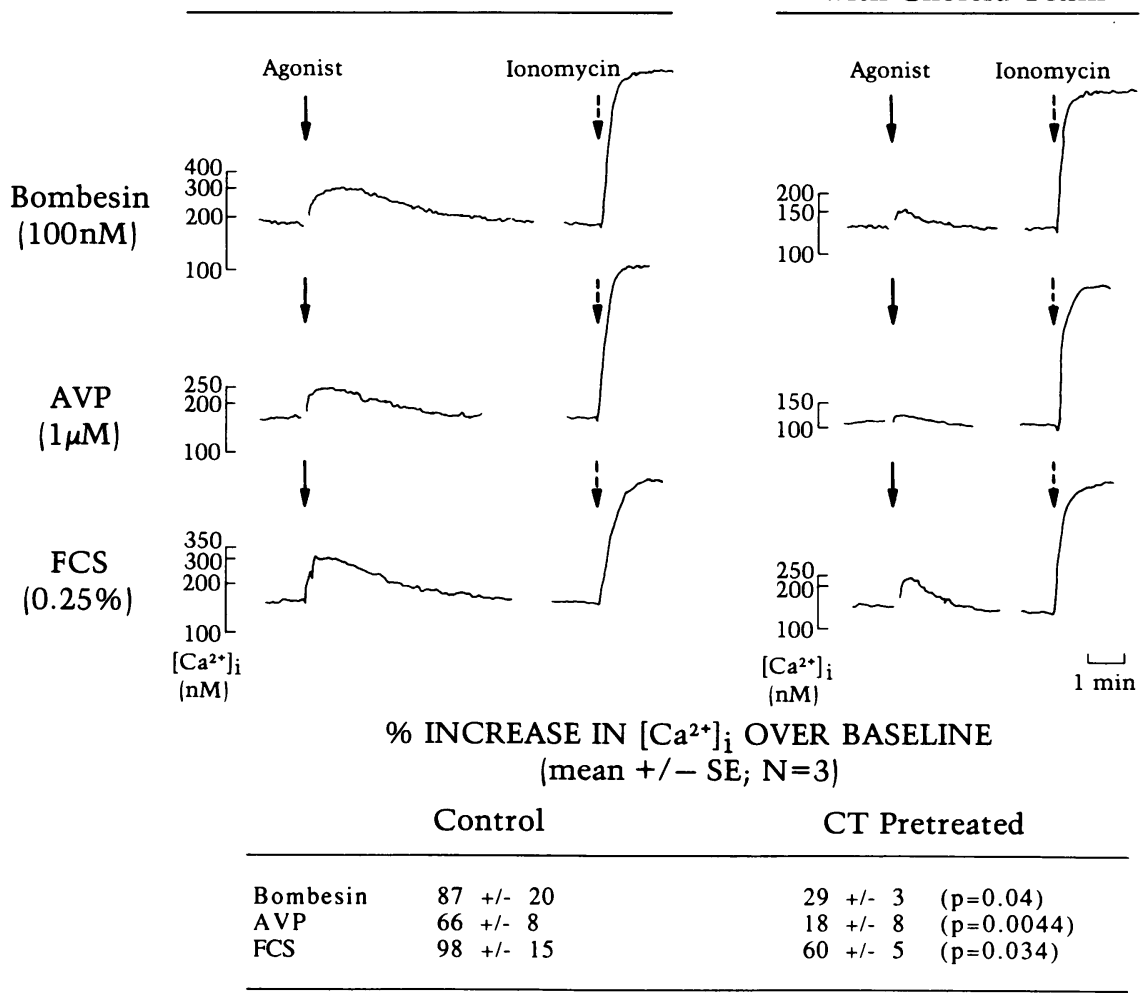

Figure 3. Effect of CT on agonist-induced increase in $\left[\mathrm{Ca}^{2+}\right]_{i}$. NCI-H345 cells were incubated overnight with or without CT at 1 $\mu \mathrm{g} / \mathrm{ml}$, then loaded with quin 2 . The experiments were performed on $5 \times 10^{6}$ cells in $2 \mathrm{ml}$ of buffer. After addition of agonist or serum at the final concentrations indicated, the intensity of fluorescence was followed. The same cells were then challenged with $2 \mu \mathrm{M}$ ionomycin to demonstrate comparable levels of quin 2 loading. The insert shows the percent increase of $\left[\mathrm{Ca}^{2+}\right]_{i}$ over baseline (mean of three experiments $\pm \mathrm{SE}$ ). Student $t$ tests on paired values yielded significant differences in all cases. 


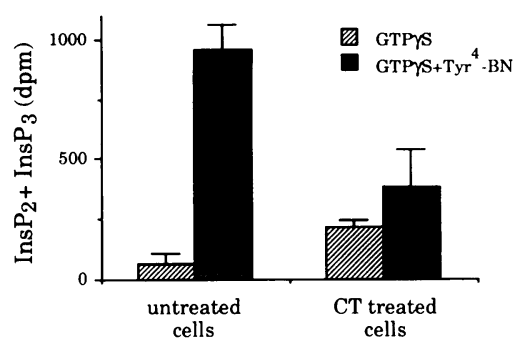

Figure 4. Inhibition of phospholipase $\mathrm{C}$ activity in membranes of NCI-H345 pretreated with CT. NCI-H345 cells were labeled with 5 $\mu \mathrm{Ci} / \mathrm{ml}\left[{ }^{3} \mathrm{H}\right]$ inositol for $5 \mathrm{~d}$, followed by treatment with or without 1 $\mu \mathrm{g} / \mathrm{ml}$ CT overnight. Membranes were prepared essentially as described (16). Membrane protein (20-50 $\mu \mathrm{g}$ ) was resuspended in $0.04 \mathrm{M}$ Tris, pH 6.9, 2 mM EGTA, $2 \mathrm{mM}$ EDTA, $10 \mathrm{mM} \mathrm{LiCl}, 2 \mu \mathrm{g} / \mathrm{ml}$ leupeptin, $0.5 \mathrm{mM}$ phenylmethylsulfonylfluoride, $1 \mathrm{mM}$ ouabain, $2 \mathrm{mM}$ DTT, $2 \mathrm{mM} \mathrm{ATP}, 0.1 \mu \mathrm{M}$ free [Ca2 $\left.{ }^{+}\right], 0.2 \mu \mathrm{M}$ free $\left[\mathrm{Mg}^{2+}\right], 10 \mu \mathrm{M} \mathrm{GTP}-\gamma-\mathrm{S}$ with or without $1 \mu \mathrm{M}$ $\left[\mathrm{Tyr}^{4}\right]$-bombesin. The disintegrations per minute in the $\left(\mathrm{IP}_{2}+\mathrm{IP}_{3}\right)$ fractions were determined as described (17). Results shown are the mean $\pm \mathrm{SE}$ of three experiments performed in triplicate normalized to time (1 min) and total DPM/assay, after subtraction of $\left(\mathrm{IP}_{2}+\mathrm{IP}_{3}\right)$ formed in basal conditions without any additions.

[Tyr $\left.{ }^{4}\right]$-bombesin displaces ${ }^{125} \mathrm{I}-\left[\mathrm{Tyr}^{4}\right]$-bombesin from NCI-H345 cells treated with CT or PT in a manner identical to that observed in control cells, with no apparent effect of CT on the binding of bombesin agonist (data not shown). In three replicate experiments, the $K_{\mathrm{d}}$ (mean $\pm \mathrm{SE}$ ) for binding of ${ }^{125} \mathrm{I}$-[ $\left.\mathrm{Tyr}^{4}\right]$-bombesin was $1.1 \pm 0.2 \mathrm{nM}$ in the control cells, $1.0 \pm 0.3 \mathrm{nM}$ in the CT-treated cells and $1.2 \pm 0.2 \mathrm{nM}$ in the PT-treated cells. The total binding expressed as femtomoles per milligram of DNA (mean \pm SE) was $48 \pm 14$ in the control cells, $52 \pm 18$ in the CT-treated cells, and $49 \pm 15$ in the PTtreated cells. The lack of effect of CT on ${ }^{125} \mathrm{I}-\left[\mathrm{Tyr}^{4}\right]$-bombesin binding is consistent with the observation that the $G$ protein coupling the GRP receptor to its effector is CT insensitive (23). These data also suggest that CT-dependent growth inhibition and abrogation of bombesin-stimulated signals observed in SCLC cannot be simply accounted for by effects on GRP binding.

Time course of CT-induced events. Because the classical effect of CT is to lead to the activation of adenylyl cyclase, the possibility that the phenomena described above are mediated by increases in intracellular cyclic AMP must be considered. Fig. $5 \mathrm{~A}$ demonstrates that in the CT-sensitive SCLC cell line $\mathrm{NCI}-\mathrm{H} 345, \mathrm{CT}$ at $1 \mu \mathrm{g} / \mathrm{ml}$ caused a rapid 10 -fold elevation in [cAMP $]_{i}$ which reached a maximum after $1 \mathrm{~h}$ but returned to baseline within $6 \mathrm{~h}$. As expected, treatment of cells with the adenylyl cyclase stimulator forskolin $(10 \mu \mathrm{M})$ also caused an acute elevation of intracellular cAMP although not to the same extent observed using CT (fourfold). The actual mean \pm SE [cAMP $]_{i}$ of three experiments observed after $1 \mathrm{~h}$ of incubation were $2.9 \pm 1.1 \mathrm{pmol} / 100 \mu \mathrm{g}$ of protein after forskolin and $6.7 \pm 1.2 \mathrm{pmol} / 100 \mu \mathrm{g}$ of protein after CT treatment. The differences between CT and forskolin treatment were not statistically significant (two-tailed paired Student $t$ test, $P=0.11$ ).

As noted above, neither forskolin at concentrations up to $10 \mu \mathrm{M}$ nor dibutyryl cAMP at concentrations up to $1 \mathrm{mM}$ affected the growth of NCI-H345 cells in vitro (Fig. 1). In addition, previous studies from this laboratory have shown that the CAMP analogues dibutyryl cAMP and 8-chloro-cAMP did not inhibit the increase in $\left[\mathrm{Ca}^{2+}\right]_{i}$ caused by the GRP ago- nist $\left[\mathrm{Tyr}^{4}\right]$-bombesin in this cell line (7). These observations strongly suggest that the CT induced elevation of intracellular cAMP cannot by itself explain the CT-related phenomena on growth and signal transduction we observed. However, we cannot exclude the possibility that transient increases in intracellular cAMP may participate in their genesis.

The time course of the inhibition by CT of the capacity of SCLC to respond to $\left[\mathrm{Tyr}^{4}\right]$-bombesin with increases in $\left[\mathrm{Ca}^{2+}\right]_{\mathrm{i}}$ and to reduce MTT to a formazan product is shown in Fig. 5 $B$. MTT reduction depends on reducing equivalents derived from mitochondrial activity and thus can be taken as an index of cellular metabolic fitness (24). After $1 \mathrm{~h}$ of incubation, at a time when the $[\mathrm{cAMP}]_{\mathrm{i}}$ is maximal, there is $\sim 50 \%$ inhibition of the increase in $\left[\mathrm{Ca}^{2+}\right]_{i}$ in response to $\left[\mathrm{Tyr}^{4}\right]$-bombesin with virtually complete preservation of the capacity to reduce MTT. Whereas this inhibition of increased $\left[\mathrm{Ca}^{2+}\right]_{i}$ in response to $\left[\mathrm{Tyr}^{4}\right]$-bombesin is maximal as early as after 2 -h of incubation with CT, the effect of CT on the intensity of MTT reduction is delayed and progresses over $72 \mathrm{~h}$. Of note, cells incubated with CT for $24 \mathrm{~h}$ are still viable as judged by the ability to exclude Trypan blue and cell lysis typically occured around the fourth or fifth day of incubation (data not shown).

For the experiments which measured effects on $\left[\mathrm{Ca}^{2+}\right]_{\mathrm{i}}$, cells were incubated with $1 \mu \mathrm{g} / \mathrm{ml} \mathrm{CT}$ at a cell density of 500,000 cells $/ \mathrm{ml}$. For the MTT experiments, cells were incubated with $1 \mu \mathrm{g} / \mathrm{ml} \mathrm{CT}$ at a cell density of 125,000 cells $/ \mathrm{ml}$. Thus relative titration of a fixed amount of CT by an excess number of cells cannot account for the delay observed in the MTT assay compared to the $\left[\mathrm{Ca}^{2+}\right]_{i}$ assay. These data indicate that the effects of CT on cellular signal transduction precede the effects on cellular metabolic activity and viability as assayed by MTT reduction and dye exclusion.

$C T$ substrates in SCLC. The principal intracellular target for CT-dependent ADP-ribosylation is $\mathrm{G}_{\alpha s}$, the stimulatory $\mathrm{G}$ protein of adenylyl cyclase. Differential expression or accessibility of $\mathrm{G}_{\alpha \mathrm{s}}$ to $\mathrm{CT}$ could therefore be a basis for the differences in cytotoxicity observed in sensitive as opposed to resistant SCLC. Previous studies have shown that four mRNAs result in two easily distinguishable major forms of $G_{\alpha s}$ protein, owing to alternative splicing of a single primary transcript (25). Utilizing an anti- $\mathrm{G}_{\mathrm{s}}$ antibody, Western blots of membrane proteins from SCLC demonstrate no difference in the expression of $\mathrm{G}_{\alpha \mathrm{s}}$ in CT-sensitive or resistant SCLC (Fig. $6 \mathrm{~A}$ ). These proteins comigrate with authentic $G_{\alpha s}$ from bovine brain. In experiments not shown here, antibodies directed against $G_{\alpha i 1}, G_{\alpha i 2}$, $G_{\alpha i 3}$, and $G_{\alpha 0}$ revealed comparable expression of these $G$ proteins in the four SCLC cell lines studied. Thus, differential inhibition of SCLC cell growth by CT does not appear to relate to the absence or enhanced expression of $G_{\alpha s}$ or of other known $G$ proteins.

Since $\mathrm{G}_{\alpha s}$ might be resistant to modification by CT in CTinsensitive cells, we examined the capacity of $\mathrm{G}_{\alpha s}$ to serve as a substrate for CT-catalyzed ADP-ribosylation in NCI-N417 membrane fractions. Fig. $6 B$ demonstrates that incubation in vitro of SCLC membranes from CT-sensitive NCI-H345 and CT-resistant NCI-N417 cells with [ $\left.{ }^{32} \mathrm{P}\right] \mathrm{NAD}$ and $\mathrm{CT}$ results in ADP-ribosylation of substrates with very similar mobility in SDS-PAGE to the $G_{a s}$ species detected by Western blotting. There is no difference apparent in the capacity of these species to undergo ADP-ribosylation in CT-sensitive as compared to CT-resistant SCLC. No other CT-dependent ADP-ribosyla- 
A

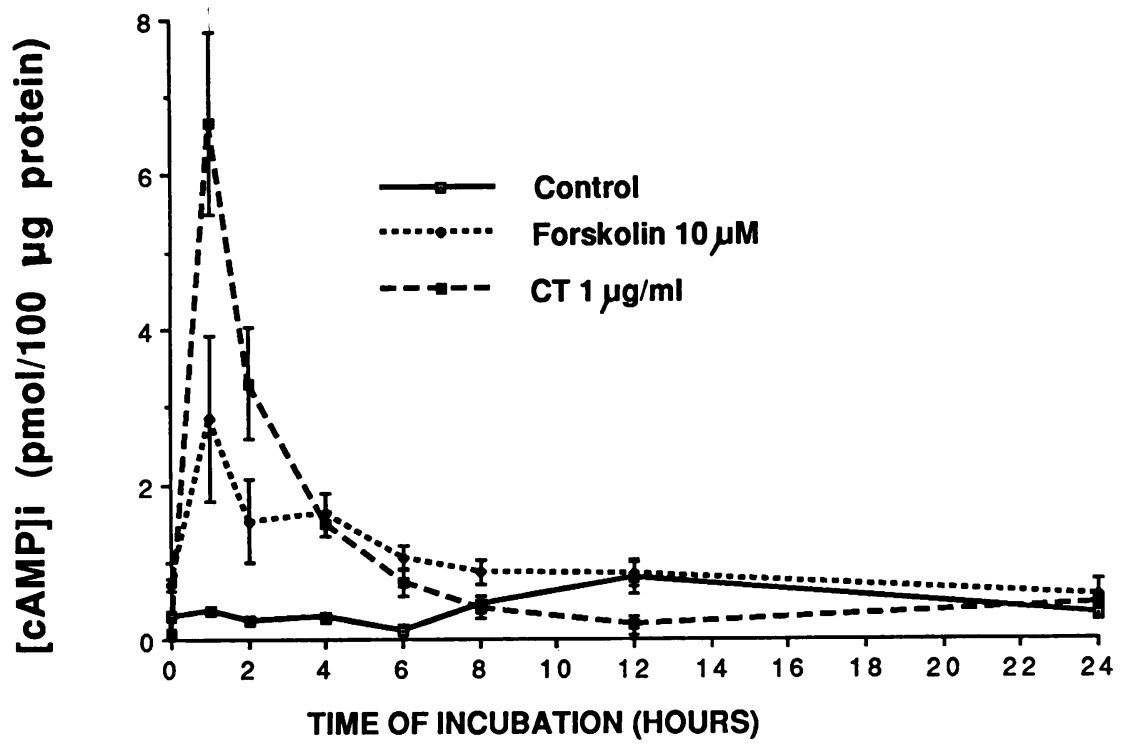

B

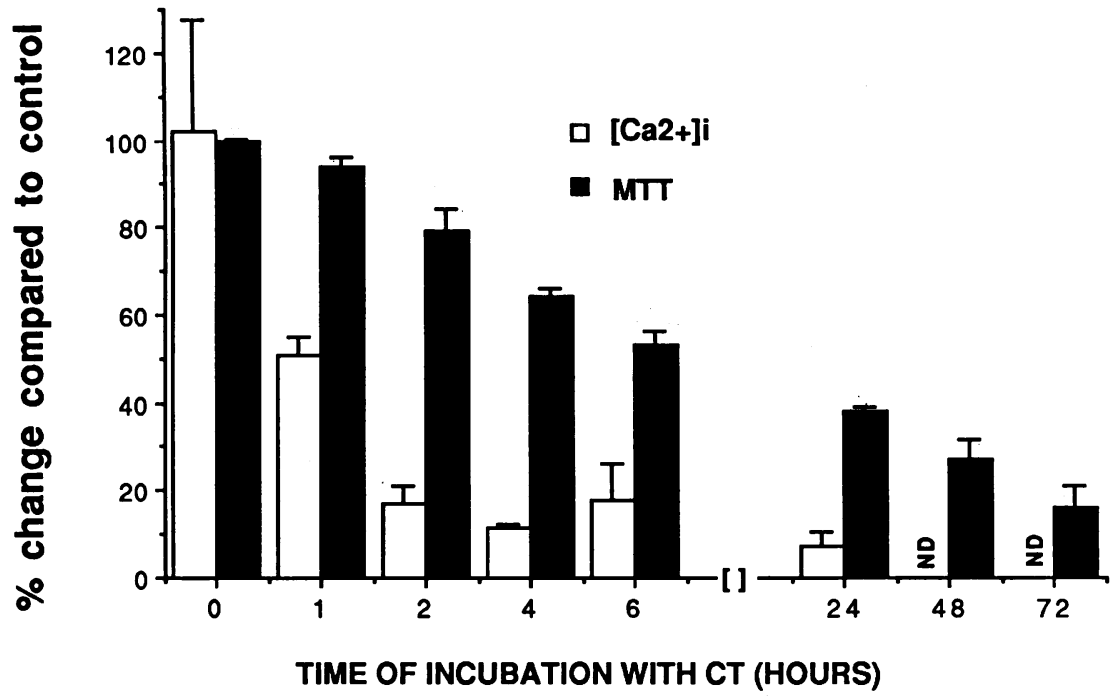

Figure 5. Time course of CT-induced events in NCI-H345. (A) $20 \times 10^{6}$ cells were incubated with the indicated concentrations of CT or forskolin for varying times. $[\mathrm{CAMP}]_{\mathrm{i}}$ was determined as described in Methods. Values shown represent the mean of three experiments $( \pm \mathrm{SE})$. (B) Time course of CT effect on [Tyr $\left.{ }^{4}\right]-$ bombesin-induced elevation in free $\left[\mathrm{Ca}^{2+}\right]_{\mathrm{i}}$ (open bars) and MTT formazan production (dark bars). At the indicated times before (time 0 ) or after addition of CT to 1 $\mu \mathrm{g} / \mathrm{ml}$, aliquots of different cell suspensions were incubated with quin 2 as described in Methods for assay of $\left[\mathrm{Tyr}^{4}\right]$-bombesin-induced increase in $\left[\mathrm{Ca}^{2+}\right]_{i}$ or were incubated with MTT for 90 min before quantitation of formazan production (this period of incubation was chosen to parallel the preparation of the cells for the quin 2 assays). The data presented shows the mean $\pm \mathrm{SE}$ of two quin 2 experiments where the response to ionomycin was comparable between all samples, and the mean \pm SE of three MTT experiments. ND, not done. tion substrates were identified by modifying GTP or NAD concentrations during the incubations or prolonging the incubations for up to $4 \mathrm{~h}$ (data not shown). The data in Fig. $6 \mathrm{~B}$ also demonstrate that the PT substrate $G_{\alpha i}$, a potential CT substrate at low efficiency of reaction (26), is similarly expressed in NCI-H345 and NCI-N417.

In contrast to the similarity between CT-resistant and CTsensitive SCLC cells in the presence and accessibility of CTdependent ADP-ribosylation substrates, Fig. $6 C$ demonstrates that the three CT-sensitive SCLC NCI-H82, NCI-H209, and NCI-H345 cell lines all had easily detectable $\mathrm{G}_{\mathrm{M} 1}$ ganglioside expression, whereas the CT-resistant NCI-N417 did not. Thus the resistance to CT-mediated growth inhibition of NCI-N417 correlates with the absence or very low expression of cell surface receptors for CT in this cell line.

\section{Discussion}

The experiments presented here demonstrate that $\mathrm{CT}$ is a potent inhibitor of the growth of human SCLC cell lines. This effect requires the holotoxin as it is not reproduced by the $\beta$ subunit alone. The cell lines sensitive to the toxin were those with easily demonstrable $\mathrm{G}_{\mathrm{M} 1}$ ganglioside, as compared to a CT-resistant SCLC cell line which has considerably lower or absent expression of this ganglioside, the binding site for CT (11).

CT or the $\beta$ subunit of CT have both been reported to have disparate effects on the growth of mammalian cells. For example, CT is a potent mitogen for Swiss 3T3 cells, acting synergistically with insulin in that system (27). The $\beta$ subunit of CT also can act as a mitogen for Swiss 3T3 cells (28) as well as 


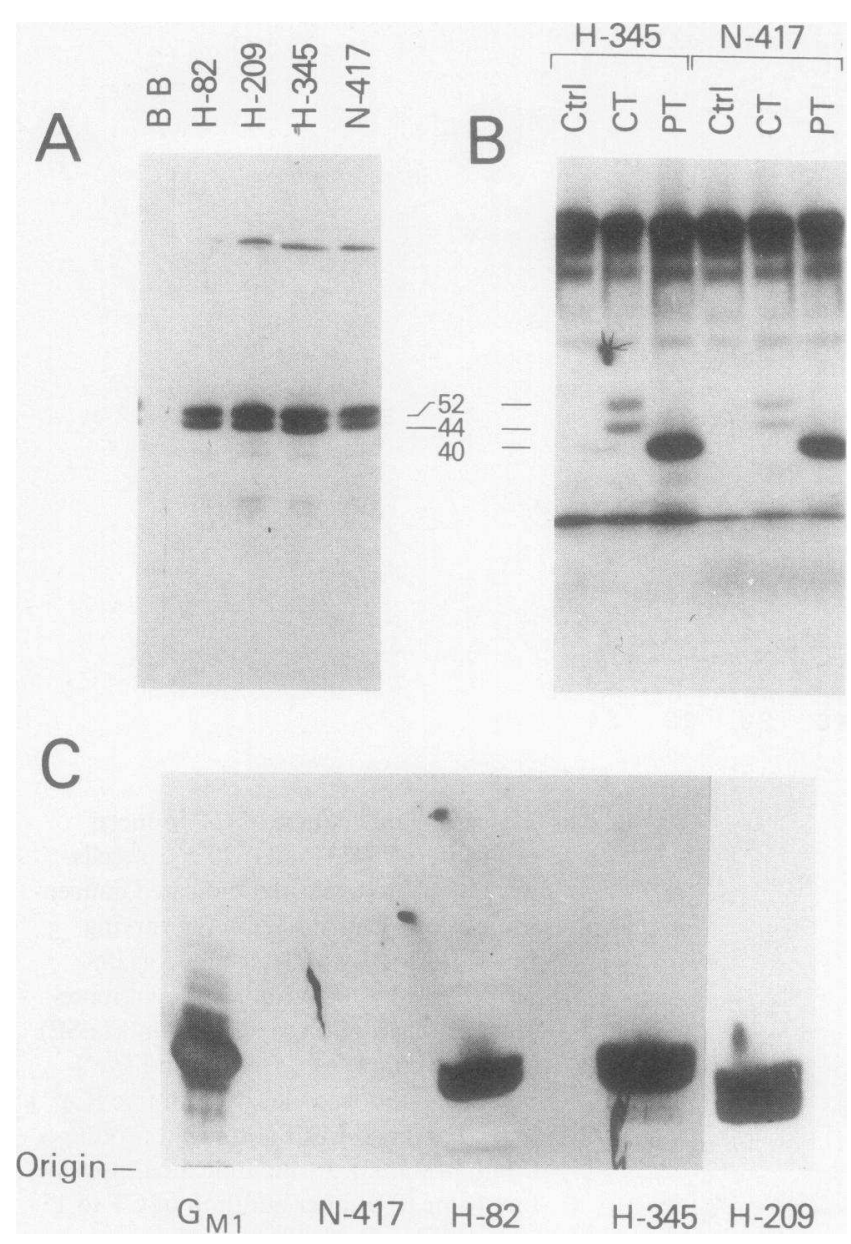

Figure 6. CT substrates in SCLC cell lines. $(A)$ Immunoblot of a bovine brain cholate extract $(B B)$ and SCLC crude membrane preparations using an anti- $\mathrm{G}_{\alpha s}$ specific antibody. $(B)$ ADP-ribosylation substrates of CT and PT in CT-sensitive and resistant cell lines. The only apparent CT substrates comigrate with authentic $\mathrm{G}_{\alpha s}$ seen in $A$. (C) Ganglioside $\mathrm{G}_{\mathrm{M} \text { 1 }}$ was determined by reaction of peroxidase-conjugated CT $-\beta$ as described in Methods using lipid extracts from the indicated cell lines.

thymic lymphocytes through a pathway involving increases in $\left[\mathrm{Ca}^{2+}\right]_{\mathrm{i}}(29)$. However, the $\beta$ subunit of CT inhibited the growth of ras-transformed Swiss 3T3 cells (28). Thus it is apparent that CT or its $\beta$ subunit can function as a growth-promoting or a growth-inhibiting influence, depending on the particular context in which it acts.

The effect of CT on the growth of normal as compared to malignant epithelial cells has also been different depending on the cell lineage studied. For example, CT stimulates the growth, alone or with other growth factors, of a variety of normal human epithelial tissues including skin keratinocytes (30), mammary (31), colonic (32), and bronchial epithelium (33). In contrast, CT inhibits the growth of the malignant counterpart of many of these tissues. Cho-Chung et al. (34) has reported inhibition of the MCF-7 human mammary carcinoma cell line by concentrations of CT similar to those we observed. In additional experiments, we have detected growth inhibition by CT in 9 of 11 SCLC cell lines (including the four studied in detail here), one of seven NSCLC cell lines, and a single colon carcinoma cell line with neuroendocrine features. In contrast, two ovarian carcinoma cell lines and the two hematopoietic cell lines, HL-60 and Hut-78, were resistant to CT. In total, 11 of 23 human cancer cell lines tested to date showed growth inhibition by CT. Moreover, two previously described rodent models have shown in vivo tumor regression after parenteral administration of CT with no detectable host toxicity $(34,35)$. Of great interest in our experiments is the apparent preferential sensitivity of lung cancer cell lines derived from patients with SCLC suggesting a cell-lineage specific susceptibility to toxin action.

Whether the presence of $G_{M 1}$ is sufficient in itself for the subsequent development of growth inhibition is unclear. It is known that exogenous ganglioside $G_{M 1}$ added to the cell culture medium can be functionally integrated into the surface membrane of intact cells and serve as the receptor for CT (36). We have attempted to reverse the CT resistance of NCI-N417 by this method. However, our efforts were complicated by the fact that $5 \mu \mathrm{M}$ or greater $\mathrm{G}_{\mathrm{M} 1}$ ganglioside inhibited the growth of this cell line. At lower concentrations, a 24-h incubation with $500 \mathrm{nM} \mathrm{G}_{\mathrm{M} 1}$ ganglioside at best only partially reversed the $\mathrm{CT}$ resistance in this cell line (percent survival at $7 \mathrm{~d}$ with 5 $\mu \mathrm{g} / \mathrm{ml}$ of CT was $71.4 \%$ for the control and $51.5 \%$ for the $\mathrm{G}_{\mathrm{M} 1}$ pretreated cells; Viallet, J., unpublished observations). In addition, preliminary experiments indicate the existence of at least some $\mathrm{G}_{\mathrm{M} 1}$ ganglioside bearing but CT resistant NSCLC cell lines (Kaur, G., and E. A. Sausville, unpublished observations).

The exact mechanism for CT-induced growth inhibition and cell death remains to be determined. Increases in cellular cAMP cannot account alone for the phenomena we observed, as independent elevations of [cAMP $]_{i}$ with forskolin or cAMP analogues fail to affect growth (Fig. 1) or [ $\left.\mathrm{Tyr}^{4}\right]$-bombesin stimulated signal transduction (7). Examples of cellular effects after CT treatment that cannot be simply accounted for by activation of $\mathrm{G}_{\alpha s}$ and stimulation of adenylyl cyclase have been noted by others. For instance, CT has been shown to inhibit the generation of inositol phosphates and cytoplasmic free calcium during $T$ cell activation $(37,38)$ as well as chemotaxis in murine macrophages (39). Neither of these phenomena could be reproduced by independent increases in cellular cAMP.

We have observed that $\mathrm{CT}$ inhibits responses to calcium mobilizing stimuli such as the mitogens $\left[\mathrm{Tyr}^{4}\right]$-bombesin, vasopressin, and fetal calf serum. Thus, one model for CT-dependent inhibition of cell growth is through the inhibition of responses to autocrine, paracrine, or exogenously added growth factors. According to this view, inhibition of growth factor-mediated signaling might cause decreased metabolic activity, leading to decreased cell growth. A manifestation of such an effect may be the disappearance of membrane ruffling which is apparent after treatment of SCLC with CT. Membrane ruffling has been related to cellular activation by growth factors and oncogenes in other systems (40-42). In fact, the same smoothing of the cell surface occurs when NCI-H345 cells maintained in RPMI- 1640 with $5 \%$ fetal calf serum are transferred to serum-free media (Viallet, J., unpublished observations).

Alternatively, the decrease in calcium-mobilizing signals could be an initial result of CT-mediated effects on cellular metabolism. Further experiments must establish whether CT causes altered availability of membrane phospholipid precursors, an alteration of the intrinsic activity of phospholipase $\mathrm{C}$, 
or modification of membrane architecture resulting in decreased response to mitogenic signals. Indeed, previous studies in rat liver have suggested an inhibition by CT of PIP and PIP synthesis $(43,44)$. While this result has been considered by some to indicate an involvement of a CT-sensitive $\mathrm{G}$ protein in the regulation of PIP kinase (45), other less direct mechanisms remain possible.

The present results reemphasize the caution that must be exercised in utilizing CT to define the participation of $\mathrm{G}$ proteins in signal transduction. Fischer and Schonbrunn (23) have demonstrated in membrane systems from a variety of bombesin-responsive tissues that CT or PT does not affect guanine nucleotide-mediated inhibition of bombesin agonist binding (23). This observation remains strong evidence that the $G$ protein coupled to the bombesin receptor and potentially involved in bombesin-mediated activation of phospholipase $\mathrm{C}$ is not modified by either CT or PT. Yet, as shown here, CT-mediated inhibition of agonist induced signals clearly can occur in the SCLC cells, again without effects on agonist binding by whole cells.

Despite uncertainty as to its exact mechanism of action, our data indicate that CT is a potent inhibitor of SCLC cell growth. Further studies must focus on whether cholera toxin based strategies employing either the toxin itself or a toxin conjugate would be suitable in developing a very novel approach to the therapy of SCLC, as well as potentially other neoplasms bearing high densities of the $G_{M}$ ganglioside receptor for this toxin. Our observations therefore have demonstrated a pathway which provides a potential target for novel therapeutic interventions in SCLC as well as perhaps other common human malignancies.

\section{Acknowledgments}

We thank Dr. A. Spiegel for antisera to Gs, Gi, Go, and for his critical review of the manuscript; Drs. S. Mumby and A. Gilman for anti-Gs antisera used in preliminary experiments; Dr. R. I. Linnoila for her expert photomicrography; and Ms. G. Kaur for cell culture.

Portions of this work conducted at Georgetown University were supported by a Division of Research Resources Biomedical Research Support Grant RR5360.

\section{References}

1. Viallet, J., and J. Minna. 1989. Gastrin-releasing peptide (GRP, mammalian bombesin) in the pathogenesis of lung cancer. Prog. Growth Factor Res. 1:89-97.

2. Carney, D. N., F. Cuttitta, T. W. Moody, and J. D. Minna. 1987. Selective stimulation of small cell lung cancer clonal growth by bombesin and gastrin-releasing peptide. Cancer Res. 47:821-825.

3. Cuttitta, F., D. N. Carney, J. Mulshine, T. W. Moody, J. Fedorko, A. Fischler, and J. D. Minna. 1985. Bombesin-like peptides can function as autocrine growth factors in human small-cell lung cancer. Nature (Lond.). 316:823-826.

4. Woll, P. J., and E. Rozengurt. 1988. [D-Arg ${ }^{1}$, D-Phe ${ }^{5}$, D-Trp ${ }^{7,9}$, Leu $^{11}$ ]substance $P$, a potent bombesin antagonist in murine Swiss 3T3 cells, inhibits the growth of human small cell lung cancer cells in vitro. Proc. Natl. Acad. Sci. USA. 85:1859-1863.

5. Trepel, J. B., J. D. Moyer, F. Cuttita, H. Frucht, D. H. Coy, R. B. Natale, J. L. Mulshine, R. T. Jensen, and E. A. Sausville. 1988. A novel bombesin receptor antagonist inhibits autocrine signals in a small cell lung carcinoma cell line. Biochem. Biophys. Res. Commun. 156:1383-1389.
6. Heikkila, R., J. B. Trepel, F. Cuttita, L. M. Neckers, and E. A. Sausville. 1987. Bombesin-related peptides induce calcium mobilization in a subset of human small cell lung cancer cell lines. J. Biol. Chem. 262:16456-16460.

7. Trepel, J. B., J. D. Moyer, R. Heikkila, and E. A. Sausville. 1988. Modulation of bombesin-induced phosphatidylinositol hydrolysis in a small-cell lung-cancer cell line. Biochem J. 255:403-410.

8. Naniberg, E., and E. Rozengurt. 1988. Temporal relationship between inositol polyphosphate formation and increases in cytosolic $\mathrm{Ca}^{2+}$ in quiescent $3 \mathrm{~T} 3$ cells stimulated by platelet-derived growth factor, bombesin and vasopressin. EMBO (Eur. Mol. Biol. Organ.) J. 7:2741-2747.

9. Swope, S. L., and A. Schonbrunn. 1988. The biphasic stimulation of insulin secretion by bombesin involves both cytosolic free calcium and protein kinase C. Biochem. J. 253:193-202.

10. Fain, J. N., M. A. Wallace, and R. J. H. Wojcikiewicz. 1988. Evidence for involvement of guanine nucleotide-binding regulatory proteins in the activation of phospholipases by hormones. FASEB (Fed. Am. Soc. Exp. Biol) J. 2:2569-2574.

11. Moss, J., and M. Vaughan. 1988. ADP-ribosylation of guanyl nucleotide-binding regulatory proteins by bacterial toxins. Adv. Enzymol. 61:303-379.

12. Yatani, A., Y. Imoto, J. Codina, S. L. Hamilton, A. M. Brown, and $L$. Birnbaumer. 1988. The stimulatory $G$ protein of adenylyl cyclase, $\mathrm{G}_{\mathrm{s}}$, also stimulates dihydropyridine-sensitive $\mathrm{Ca}^{2+}$ channels. Evidence for direct regulation independent of phosphorylation by cAMPdependent protein kinase or stimulation by a dihydropyridine agonist. J. Biol. Chem. 263:9887-9895.

13. Carney, D. N., A. F. Gazdar, G. Bepler, J. G. Guccion, P. J. Marangos, T. W. Moody, M. H. Zweig, and J. D. Minna. 1985. Establishment and identification of small cell lung cancer cell lines having classic and variant features. Cancer Res. 45:2913-2923.

14. Carmichael, J., W. DeGraff, A. Gazdar, J. Minna, and J. Mitchell. 1987. Evaluation of a tetrazolium-based semiautomated colorimetric assay: assessment of chemosensitivity testing. Cancer Res. 47:936-942.

15. Mosmann, T. 1983. Rapid colorimetric assay for cellular growth and survival: application to survival and cytotoxicity assays. $J$. Immunol. Methods. 65:55-63.

16. Straub, R. E., and M. Gershengorn. 1986. Thyrotropin-releasing hormone and GTP activate inositol trisphosphate formation in membranes isolated from rat pituitary cells. J. Biol. Chem. 261:27122717.

17. Berridge, M. J., C. P. Downes, and M. R. Hanley. 1982. Lithium amplifies agonist-dependent phosphatidylinositol responses in brain and salivary glands. Biochem. J. 206:587-595.

18. Sharoni, Y., J. Viallet, J. B. Trepel, and E. A. Sausville. 1990. Effect of guanine and adenine nucleotides on bombesin-stimulated phospholipase-C activity in membranes from Swiss 3T3 and small cell lung carcinoma cells. Cancer Res. 50:5257-5262.

19. Laemmli, U. K. 1970. Cleavage of structural proteins during the assembly of the head of bacteriophage T4. Nature (Lond.). 227:680-685.

20. Towbin, H., T. Staehelin, and J. Gordon. 1979. Electrophoretic transfer of proteins from polyacrylamide gels to nitrocellulose sheets: procedure and some applications. Proc. Natl. Acad. Sci. USA. 76:4350-4354.

21. Simonds, W. F., P. K. Goldsmith, J. Codina, C. G. Unson, and A. M. Spiegel. 1989. Gi2 mediates alpha2-adrenergic inhibition of adenylyl cyclase in platelet membranes: in situ identification with Galpha C-terminal antibodies. Proc. Natl. Acad. Sci. USA. 86:78097813.

22. Magnani, J. L., D. F. Smith, and V. Ginsburg. 1980. Detection of gangliosides that bind cholera toxin: direct binding of ${ }^{125}$ I-labeled toxin to thin-layer chromatograms. Anal. Biochem. 109:399-402.

23. Fischer, J. B., and A. Schonbrunn. 1988. The bombesin recep- 
tor is coupled to a guanine nucleotide-binding protein which is insensitive to pertussis and cholera toxins. J. Biol. Chem. 263:2808-2816.

24. Gerlier, D., and N. Thomasset. 1986. Use of MTT colorimetric assay to measure cell activation. J. Immunol. Methods. 94:57-63.

25. Bray, P., A. Carter, C. Simons, V. Guo, C. Puckett, J. Kamholz, A. Spiegel, and M. Niremberg. 1986. Human cDNA clones for four species of Galphas signal transduction protein. Proc. Natl. Acad. Sci. USA. 83:8893-8897.

26. Milligan, G. 1987. Guanine nucleotide regulation of the pertussis and cholera toxin substrates of rat glioma C6BU1 cells. Biochim. Biophys. Acta. 929:197-202.

27. Rozengurt, E. 1986. Early signals in the mitogenic response. Science (Wash. DC). 234:161-166.

28. Spiegel, S., and P. H. Fishman. 1987. Gangliosides as bimodal regulators of cell growth. Proc. Natl. Acad. Sci. USA. 84:141-145.

29. Dixon, S. J., D. Stewart, S. Grinstein, and S. Spiegel. 1987. Transmembrane signalling by the B subunit of cholera toxin: increased cytoplasmic free calcium in rat lymphocytes. J. Cell Biol. 105:11531161.

30. Green, H. 1978. Cyclic AMP in relation to proliferation of the epidermal cell: a new view. Cell. 15:801-811.

31. Taylor-Papadimitriou, J., P. Purkis, and I. S. Fentiman. 1980. Cholera toxin and analogues of cyclic AMP stimulate the growth of cultured human mammary epithelial cells. J. Cell. Physiol. 102:317321.

32. Chopra, D. P., K. M. Siddiqui, and R. A. Cooney. 1987. Effects of insulin, transferrin, cholera toxin, and epidermal growth factor on growth and morphology of human fetal normal colon epithelial cells. Gastroenterology. 92:891-904.

33. Lechner, J. F., A. Haugen, H. Autrup, I. A. McClendon, B. F. Trump, and C. C. Harris. 1981. Clonal growth of epithelial cells from normal adult bronchus. Cancer Res. 41:2294-2304.

34. Cho-Chung, Y. S., T. Clair, C. Shepheard, and B. Berghoffer. 1983. Arrest of hormone-dependent mammary cancer growth in vivo and in vitro by cholera toxin. Cancer Res. 43:1473-1476.

35. Holmgren, J., S. Lange, L. Lindholm, C. Lon̈nroth, and I. Lon̈nroth. 1977. In vivo modulation of intracellular cAMP and cell growth of a lymphatic tumor in mice by cholera toxin. Exp. Cell Res. 108:31-39.

36. Moss, J., P. H. Fishman, V. C. Manganiello, M. Vaughan, and R. O. Brady. 1976. Functional incorporation of ganglioside into intact cells: induction of choleragen responsiveness. Proc. Natl. Acad. Sci. USA. 73:1034-1037.

37. Imboden, J. B., D. M. Shoback, G. Pattison, and J. D. Stobo. 1986. Cholera toxin inhibits the T-cell antigen receptor-mediated increases in inositol trisphosphate and cytoplasmic free calcium. Proc. Natl. Acad. Sci. USA. 83:5673-5677.

38. Stewart, S. J., V. Prpic, J. A. Johns, F. S. Powers, S. E. Graber, J. T. Forbes, and J. H. Exton. 1989. Bacterial toxins affect early events of T lymphocyte activation. J. Clin. Invest. 83:234-242.

39. Aksamit, R. R., P. S. Backlund, and G. L. Cantoni. 1985. Cholera toxin inhibits chemotaxis by a cAMP-independent mechanism. Proc. Natl. Acad. Sci. USA. 82:7475-7479.

40. Brunk, U., J. Schellens, and B. Westermarck. 1976. Influence of epidermal growth factor (EGF) on ruffling activity, pinocytosis and proliferation of cultivated human glia cells. Exp. Cell Res. 103:295302.

41. Goshima, K., A. Masuda, and K. Owaribe. 1984. Insulin-induced formation of ruffling membranes of $\mathrm{KB}$ cells and its correlation with enhancement of amino acid transport. J. Cell Biol. 98:801-809.

42. Bar-Sagi, D., and J. R. Feramisco. 1986. Induction of membrane ruffling and fluid-phase pinocytosis in quiescent fibroblasts by ras proteins. Science (Wash.DC). 233:1061-1068.

43. Biffen, M., and B. R. Martin. 1987. Polyphosphoinositide labeling in rat liver plasma membranes is reduced by preincubation with cholera toxin. J. Biol. Chem. 262:7744-7750.

44. Urumow, T., and O. H. Wieland. 1988. Evidence for a cholera toxin sensitive G-protein involved in the regulation of phosphatidylinositol 4-phosphate kinase of rat liver membranes. Biochim. Biophys. Acta. 972:232-238.

45. Smith, C. D., and K. J. Chang. 1989. Regulation of brain phosphatidylinositol-4-phosphate kinase by GTP analogues: A potential role for guanine nucleotide regulatory proteins. J. Biol. Chem. 264:3206-3210. 